\title{
THE LIFE AND WORK OF DONALD OLDING HEBB, CANADA'S GREATEST PSYCHOLOGIST
}

\author{
RICHARD E. BROWN \\ Department of Psychology \\ Dalhousie University \\ Halifax, Nova Scotia B3H 4J1
}

\begin{abstract}
Donald Olding Hebb's lasting influence in psychology and neuroscience stems largely from his influential book, The Organization of Behavior (Hebb 1949a) in which he introduced the concepts of synaptic change and cell assemblies to explain the neural events underlying behaviour. Hebb's work revolutionized psychology by establishing a biological basis for psychological phenomena and expounding a neuropsychological theory which provided the structure for the development of the fields of cognitive and behavioural neuroscience. His ultimate fame could not have been predicted from his performance at Dalhousie University nor from his early career as a teacher. His career as a psychologist began as a night school student in psychology at McGill University in 1928. After completing his MA in psychology at McGill in 1932, he studied with Karl Lashley at the University of Chicago completing his PhD with Lashley at Harvard in 1936. For the next two years he conducted neuropsychological tests on the patients of Dr. Wilder Penfield at the Montreal Neurological Institute and from 1939 to 1942 was a professor at Queen's University in Kingston, Ontario. He spent the next five years studying emotionality in chimpanzees at the Yerkes Primate Center in Florida where he began to write The Organization of Behavior. Hebb became a professor of Psychology at McGill University in 1947 and head of his department in 1948 where he completed his book and directed an internationally recognized graduate program in physiological psychology. Elected President of the Canadian Psychological Association in 1952 and the American Psychological Association in 1960 he also became a Fellow of the Royal Societies of Canada and England. Late in his career, he was Vice Dean of Biological Sciences (1964-66) and then Chancellor of McGill University (1970-74). Upon retirement from McGill, he moved back to Nova Scotia and became a professor emeritus at Dalhousie University from 1978 until his death in 1985. During this time he wrote his last book, Essay on Mind (Hebb 1980a). He was inducted into the Canadian Medical Hall of Fame in October 2003.
\end{abstract}

L'influence durable de Donald Olding Hebb dans les domaines de la psychologie et de la neuroscience est en grande partie le résultat de son ouvrage prestigieux The Organization of Behavior (1949) dans lequel il présente les concepts de modification synaptique et de réseau neuronal pour expliquer les phénomènes neuronaux qui sous-tendent le comportement. M. Hebb a révolutionné le domaine de la psychologie en établissant une base biologique pour des phénomènes psychologiques et en expliquant une théorie neuropsychologique qui a fourni la structure nécessaire au développement des domaines de la neuroscience cognitive et comportementale. Sa renommée n'aurait pu être prédite à partir de sa performance à l'Université Dalhousie ou de son poste d'enseignant au début de sa carrière. Sa carrière dans le domaine de la psychologie a débuté lorsqu'il a commencé à suivre des cours du soir dans le domaine à l'Université McGill en 1928. Après avoir obtenu une maîtrise en psychologie à l'Université McGill en 1932, il a étudié aux côtés de Karl Lashley à l'Université de Chicago pour finalement obtenir un doctorat avec M. Lashley à l'Université Harvard en 1936. Au cours des deux années suivantes, il a effectué des tests neuropsychologiques sur les patients du docteur Wilder Penfield à l'Institut neurologique de Montréal. De 1939 à 1942, il a été professeur 
à l'Université Queen's, à Kingston en Ontario. II a passé les cinq années suivantes à étudier les émotions chez le chimpanzé au Yerkes Primate Center en Floride. C'est au cours de cette période qu'il a commencé à rédiger The Organization of Behavior. M. Hebb a ensuite occupé un poste de professeur de psychologie à l'Université McGill en 1947 et il a été nommé chef du département de psychologie en 1948, poste dans le cadre duquel il a dirigé un programme d'études supérieures de renommée internationale en psychophysiologie. C'est à cette période qu'il a terminé son ouvrage prestigieux. Élu président de la Société canadienne de psychologie en 1952 et de l'American Psychological Association en 1960, il a également été un Membre de la Société royale du Canada et un membre de la Royal Society of England. Vers la fin de sa carrière, il a occupé le poste de vice-doyen des sciences biologiques à l'Université McGill (de 1964 à 1966) puis de chancelier de cette même université (de 1970 à 1974). Au moment de sa retraite de l'Université McGill, M. Hebb est retourné en Nouvelle-Écosse. II a été professeur émérite à l'Université Dalhousie de 1978 jusqu'à sa mort en 1985, période durant laquelle il a rédigé son dernier ouvrage Essay on Mind (1980a). Il a été intronisé au Temple de la renommée médicale canadienne en octobre 2003.

\section{Hebb's accomplishments}

The accomplishments that made Donald Olding Hebb famous in psychology in Canada and the rest of the world are of three types. First, was his determination to demonstrate, in theory and by experiment, that each type of behaviour studied by psychologists was the result of brain function. In providing arguments for this proposition, Hebb developed a theory that integrated data from many disparate areas of psychology into a single neuropsychological theory. Second, Hebb created research areas in psychology that had not existed before. These included the effects of environmental enrichment and sensory deprivation on behaviour and the idea of perceptual learning. His two most fundamental concepts, the ideas of synaptic change and cell assemblies led to a physiological model of the cognitive functions underlying motivation, emotion, thought and consciousness. Third, through his teaching of undergraduate and graduate students in the Psychology Department at McGill University, Hebb founded the areas of Behavioural and Cognitive Neuroscience, which shaped the development of psychology and neuroscience in Canada. Hebb's ideas were promoted by his students as they built laboratories in universities across Canada and the world. Today the terms "Hebb synapse", "Hebbian cell assembly" and "Hebbian learning mechanism" are basic concepts, not only in psychology and neuroscience, but also in physics and computer science, where they are used in computer models of learning and memory.

\section{Hebb's family}

Donald Olding Hebb was born into a family whose roots are as old as British Nova Scotia. Much of what we know about his life comes from his published autobiography (Hebb 1980b) and an unpublished autobiography (Hebb 1980c). Hebb's great-great-great grandfather, Johann Adam Heb (1738-1803) emigrated to Nova Scotia from what is now Germany at the age of 12 and settled in Lunenburg County in 1753 (Teal 1994). All of the Hebbs in Nova Scotia are descended from Adam Heb. Hebb's grandfather, Solomon Hebb (1839-1935) was a millwright and his children were the first 
of the Hebbs to attend Dalhousie University. Hebb's father, Arthur Morrison Hebb (1872-1959) received a BA (1899) and an MD (1902). His brother, Thomas Carlyle Hebb (1878-1938) received a BA (1900), MA (1901) and BSc (1902) from Dalhousie and went on to receive a PhD in Physics from the University of Chicago (1904). He taught Physics at the University of British Columbia (UBC) from 1916 until his death in 1938. His sister, Bertha Boyd Hebb (1869-1954) was the first woman from Lunenburg County to graduate from Dalhousie University, receiving her BA in 1894 and MA in 1898. She became a teacher and spent most of her career in South Africa.

Hebb's mother, Mary Clara Olding (1870-1921) was descended from Nicholas Purdue Olding (1751-1845), who was the first practising lawyer in Pictou County and came to be known as "the father and grandfather of the bar" (Olding 1976, Patterson 1955). She attended the Pictou Academy and entered medical school at Dalhousie University in 1892, receiving an MD in 1896. She was the third woman to receive an MD from Dalhousie University (MacLeod 1990) and had a medical practice in Saint John, New Brunswick, before marrying Arthur Morrison Hebb in 1903 and joining him in his practice in Chester, Nova Scotia.

Donald Olding Hebb was born on 22 July 1904, the first of four children (see Fig 1); he had two brothers, Andrew (1905-2005) and Peter (19091955), and a sister, Catherine (1912-1978). All of the Hebb children went on to pursue distinguished careers. Andrew received a BA (1925) and a law degree (1927) from Dalhousie and became a journalist and then the founding chief executive of the Co-operators Insurance Company. Peter

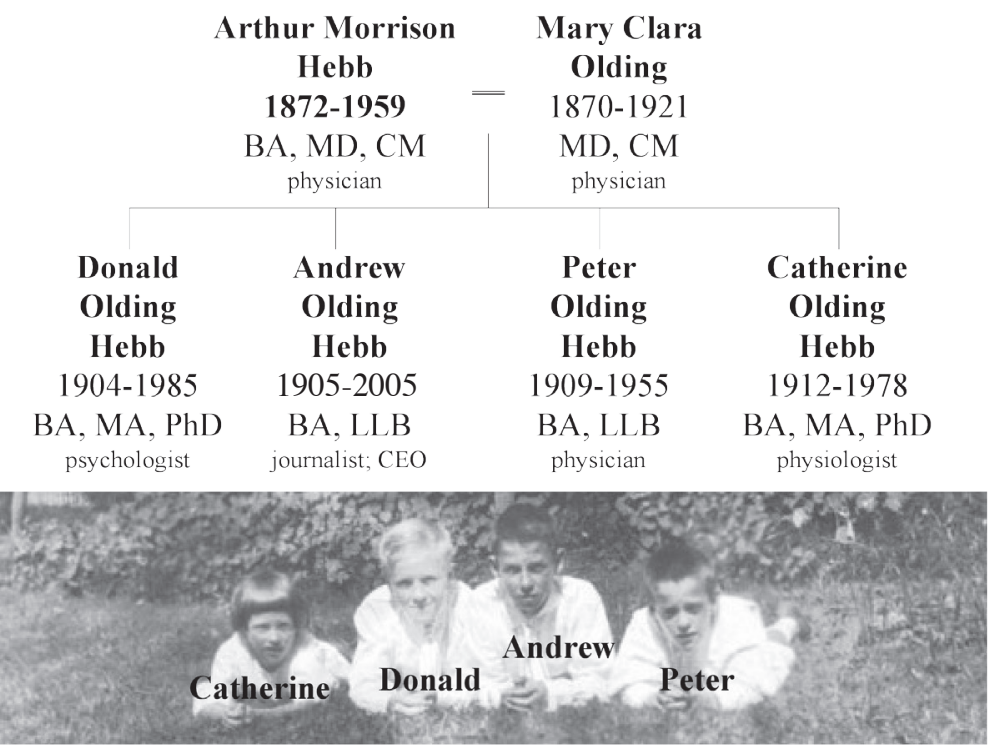

Fig 1. Hebb and his siblings. Hebb's family all received degrees from Dalhousie University and went on to distinguished careers. From Gordon Hebb. 
received an MD (1934) from Dalhousie and was a physician in Dartmouth, Nova Scotia. Catherine received a BA in Biology (1932) and an MA in Pharmacology (1933) from Dalhousie and a PhD in Physiology from McGill University (1937), where she studied the physiology of the digestive system in the laboratory of Dr. Boris Babkin. She started teaching in the Department of Physiology at the University of Edinburgh in 1938 and spent a year at the physiological laboratory at Cambridge University (1945), where she began her research on the biosynthesis of acetylcholine. In 1952 she joined the Institute of Animal Physiology at Babraham, Cambridge, and continued to work on acetylcholine until the end of her career (Silver 1993).

\section{Hebb's education in Nova Scotia}

As his brother Andrew was ill as a child, they were both taught at home by their mother, who was an advocate of the Montessori method (Hebb 1980b). Donald was an avid reader and, after entering the Chester School in the second grade at 8 years of age, he was rapidly promoted. He completed grades 2, 3 and 4 in his first year at school and then grades 5 and 6 in his next year and reached the ninth grade when only 12 years old (Hebb 1980b). School work came easily to him and, after winning a school spelling competition in the seventh grade, he did little studying. As the result of lax teaching and poor study habits, he, and most of his classmates, failed grade eleven and had to repeat the year. In 1920, the family moved to Dartmouth, Nova Scotia where Donald and Andrew completed grade 12 at the Halifax County Academy. The first major crisis in his life occurred in July 1921, when his mother died of cancer, just before he and Andrew entered Dalhousie University. Although his father wanted him to take math and physics like his uncle, Thomas Carlyle Hebb, Donald entered the Faculty of Arts and majored in English and philosophy, with the intention of becoming a novelist (Hebb 1980b).

When Hebb was a student, psychology was taught in the Philosophy Department at Dalhousie. A separate Psychology Department was not formed until 1948. We do know, however, that Hebb was exposed to psychology in two of his Philosophy classes: Philosophy 1 (Logic and Psychology) taught by H.L. Stewart, and Philosophy 9 (Experimental Psychology), taught by Norman J. Symons. During his last two years at Dalhousie, Hebb worked on the Dalhousie Gazette student newspaper, in which he published a number of poems. He was also the historian of the class of 1925 (Hebb 1925). After graduating, he took summer classes to obtain a teaching certificate from the Provincial Normal School in Truro, Nova Scotia, and became the principal of his old school in Chester.

\section{Hebb as a teacher and graduate student in Montreal: 1926-34}

After teaching in Chester for only one year, Hebb spent the summer of 1926 working as a laborer on a farm in Alberta, where it is thought that he contracted tuberculosis. Hebb then moved to Montreal, where he became a teacher in Verdun. During this time, he met Professor W.D. Tait, the 
Head of the Psychology Department at McGill, and attended Dr. Tait's night school class in psychology for teachers. From 1928 to 1930, Hebb taught at Rushbrooke School in Verdun, and was a part-time graduate student in psychology at McGill under the supervision of Professor Chester Kellogg. During this time Hebb started his educational experiment. As a teacher and principal, Hebb found that students of all intellectual abilities were failing in school. He decided to change the school procedures to facilitate education and persuade the children that schoolwork was a privilege. He gave the students interesting things to do in class and no homework. Students were not punished for inattention and those who disrupted the class were sent outside to play. He described this experiment in a teacher's journal (Hebb 1930 ) and continued with it for four years.

During the 1930-31 school year, Hebb was bedridden with tuberculosis of the hip, which left him with a permanent limp. He convalesced at his father's home in Dartmouth, Nova Scotia, and met Isabel Clark, the daughter of a Halifax clergyman, whom he married in 1931. While he was bedridden, Hebb studied Sherrington's Integrative Action of the Nervous System and Pavlov's Conditioned Reflexes, and wrote a theoretical MA thesis (Hebb 1932). This thesis is of interest because it contains Hebb's first thoughts on the nature of synaptic activity during conditioning (Brown \& Milner 2003). It was passed by two examiners, Professor Kellogg of the Psychology Department and Professor Boris P. Babkin of the Physiology Department at McGill. Babkin had worked with Pavlov in St. Petersburg and held a Chair in Physiology at Dalhousie (1924-28) before becoming a Research Professor in Physiology at McGill (Babkin 1942). After the completion of his MA thesis, Hebb worked in Babkin's laboratory, studying Pavlovian conditioning with Leonid Andreyev who had also worked with Pavlov.

Hebb continued his teaching career while he was working on his PhD at McGill, but 1933-34 was a terrible year for him and he decided to leave Montreal. First, the Protestant School Board of Montreal terminated his educational experiment (Hebb 1980b). This appears to have coincided with the appointment of a new school inspector in Verdun. Second, he became disillusioned with Pavlovian conditioning procedures and his graduate studies at McGill. Most of the faculty in Psychology were engaged in Educational Psychology and Intelligence Testing, whereas Hebb was becoming increasingly interested in Physiological Psychology. Third, Hebb and his wife were in a car accident near New Glasgow, Nova Scotia and she died on his birthday in 1933 (Hebb 1980b).

\section{PhD research with Karl Lashley: 1934-37}

Following the advice of Professor Babkin, Hebb went to study at the University of Chicago in July 1934 with Lashley, the world's leading Physiological Psychologist, who had just published an influential book on the neural basis of intelligence (Lashley 1929). Lashley had been the president of the American Psychological Association, and his presidential address summarized the state of the art in the physiological study of behaviour 
(Lashley 1930). In Chicago, Hebb had classes with some of the foremost Professors of Psychology in America. He took Physiological Psychology from Karl Lashley, Psychological Testing from Forrest A. Kingsbury, Factor Analysis from L.L. Thurstone, Learning from Harvey A. Carr (the Head of the Psychology Department) and a seminar in Gestalt Psychology from Wolfgang Kohler. He also had a course in physiology from Nathaniel Kleitman and a course in anatomy from C.J. Herrick. During the time that Hebb was at Chicago it was the centre of Functional Psychology, with a focus on the biological basis of behaviour (Dewsbury 2002, Kingsbury 1946), an approach that he was to follow for the rest of his career.

Only a year after Hebb arrived in Chicago, however, Lashley accepted a position at Harvard University and Hebb moved with him to Harvard to complete his PhD. At Harvard, Hebb worked on the visual abilities of rats reared in the dark (Hebb 1936) and received his degree in 1936. For the next year, Hebb worked as a Research Assistant for Lashley and as an Instructor in Introductory Psychology for Professor E. G. Boring. During this year, Hebb published his PhD research (Hebb 1937) and completed the research that he had started in Chicago on field orientation in rats (Hebb 1938). In 1937, Hebb married Elizabeth Donovan, who had studied Education and Sociology at the University of Chicago. She became the mother of his two daughters, Jane and Mary Ellen.

\section{Neuropsychology at the Montreal Neurological Institute: 1937-39}

In 1937, Hebb's sister Catherine, who was a PhD student with Babkin at McGill University, informed him that Wilder Penfield, the founder of the Montreal Neurological Institute (MNI), was looking for someone to study the psychological effects of his neurosurgical procedures. Penfield was the leading neurosurgeon of his day, and specialized in surgery for epilepsy (Bell 1977, Feindel 1992). Hebb was appointed as a Rockefeller Fellow and Lecturer in Clinical Psychology at the MNI in 1937 and worked with patients who had temporal lobe and frontal lobe surgery. Hebb's most complete study was of patient KM, who was tested before and after a frontal lobotomy. Much to his surprise, Hebb found little effect of the surgery on KM's scores on the standardized psychological tests available at the time (Hebb \& Penfield 1940) and he concluded that the removal of large amounts of frontal lobe tissue either had no effect on the mental abilities of the patient or that the tests available were not sensitive enough to detect the effects of the surgery (Hebb 1939a, Hebb \& Penfield 1940).

Hebb's experience in testing patients at the MNI led him to develop a theory about the nature of intelligence and how it should be tested. First, he found that the Stanford Binet and the Wechsler Intelligence tests were inadequate for use with adult patients who had low verbal ability and who did not speak English (Hebb \& Morton 1944). So, along with professor N.W. Morton of the McGill Psychology Department, Hebb began to develop two new tests: the verbal Adult Comprehension Test and the non-verbal Picture Anomaly Test (Hebb \& Morton 1943). Second, Hebb observed that 
lesions of different brain areas produced different cognitive impairments. He began to believe that intelligence was not a unitary entity but a complex phenomenon, whose multiple components could be differently affected by cerebral lesions. As a result he developed the idea that rather than measuring overall intellectual change, one should determine the specific aspects of intelligence affected by brain lesions using specific neurological tests (Hebb 1939b). Third, Hebb came to believe that intelligence had two components: a fixed or biological component and a variable component that could be influenced by environmental experience (Hebb 1942). Fourth, Hebb found that the age at which a brain injury occurred was important in determining its effects on intelligence. Certain abilities were affected more by early than late injury, while the age at injury was not important for other abilities (Hebb 1939b, 1942). These findings, important for the development of Hebb's ideas on the neural control of behaviour, surfaced many times throughout Hebb's career.

\section{Hebb at Queen's University: 1939-42}

When his Fellowship at the MNI ended in 1939, Hebb took a position as a Lecturer in the Department of Mental and Moral Philosophy at Queen's University. Here he taughtPhilosophy 2 (Psychology), an elementary survey of mental life, Philosophy 30 (Problems in Psychology) in which students conducted "a specific experimental problem of a minor character", Philosophy 4 (Contemporary Psychology), a survey of present-day psychology, and Philosophy 15 (Experimental Psychology) and also had students conduct laboratory experiments (Queen's University 1940-41).

Despite this heavy teaching load at Queen's, Hebb managed to publish his studies on the effects of brain lesions at different ages (Hebb 1942), a review of frontal lobe function (Hebb 1945a) and also completed two research projects with his students. Hebb \& Williams (1946) designed a variable path maze and this Hebb-Williams maze has since been used in a plethora of comparative studies of learning in animals and humans (Shore et al. 2001). Hebb \& Foord (1945) tested and refuted the Gestalt hypothesis of dynamic activity within the memory trace. However, Hebb was not highly paid at Queen's and had to earn extra money to support his family by teaching summer school and marking extramural essays in addition to his regular load of four full courses (Hebb 1980d).

While Hebb was at Queen's University, Professor Humphrey, the Head of the Psychology Department at Queen's, and Professor Bott, from the University of Toronto, brought together a number of psychologists to assist the war effort and this group founded the Canadian Psychological Association (CPA) in 1940. The first accomplishment of this group was the development of the M-test, an Army classification test for new recruits developed primarily by N.W. Morton (Ferguson 1993). The first issue of the Bulletin of the Canadian Psychology Association (the forerunner of the Canadian Psychologist) was published in October 1940 with Hebb as the editor from December 1940 until 1942. When the first meeting of the CPA was held 
at McGill University in December 1941, Hebb (1941) presented a paper entitled "Higher level difficulty in verbal test material".

Hebb was promoted to Assistant Professor at Queen's in 1941, but even with a increase in salary to $\$ 2400$ per year, he was not able to support his family of four (his second daughter was born in Kingston in 1941). Thus, Hebb began to search for a better paying position that would allow him more time for research.

\section{Hebb at the Yerkes Primate Research Laboratory: 1942-47}

When Karl Lashley succeeded Robert Yerkes as the director of the Yale Primate Laboratories at Orange Park, Florida in 1942, he offered Hebb a position as a research scientist at a salary of $\$ 4000$ per year. The position included an appointment in the Department of Psychology at Harvard, one month of vacation per year, $\$ 200$ per year for travel and expenses for scientific meetings. This was exactly the sort of position that Hebb was seeking and he moved to Florida in September 1942. There he was employed as a Research Associate (1942-45) and then as a Harvard University Research Fellow (1945-1947). The travel money was spent on trips to Montreal to continue his collaboration with Penfield.

During his years in Florida, Hebb studied fear and anger in chimpanzees (Hebb 1945b, 1949b) and related these findings to human emotionality (Hebb 1946, 1947a). He also studied the behaviour of dolphins (McBride \& Hebb 1948) and continued his work on the development of rat intelligence. To determine the effects of early experience on learning, Hebb and his daughters reared rats as pets at home and showed that this enriched experience resulted in improved maze learning in adulthood (Hebb 1947b). These studies formed the basis of studies on the effects of environmental enrichment on behaviour and neural development (Krech et al. 1962) that has become one of the most important concepts in developmental psychology and continues to influence research on neural and behavioural development (van Praag et al. 2000).

\section{Writing The Organization of Behavior: 1944-1949}

During his years in Florida, Hebb completed the first five chapters of the manuscript of a book, eventually published under the title The Organization of Behavior, in which he outlined an entirely new way of understanding behaviour in terms of brain function. Hebb discussed how he came to write The Organization of Behavior in two autobiographical memoirs (Hebb 1959, 1980b). In short, his previous research on the effects of brain lesions at different ages on intelligence (Hebb 1942) led him to the conclusion that intelligence must be a product of both innate ability and learning experience. He began to ask how the concepts, modes of thought, and ways of perceiving, which constitute intelligence, could be conceived in terms of neural mechanisms (Hebb 1980b).

Hebb made notes for The Organization of Behavior between June 1944 and March 1945. These notes outline a set of physiological explanations for psychological processes such as attention, perception and learning (Hebb 
1945c). It is in these notes that Hebb worked out the basic propositions of his neuropsychological theory, which he said was "not merely a translation [of psychological data] into physiological terms, but suggests the basis of considerable synthesis and makes possible an intelligible formulation of the problems of attention and thought, as a function of central processes" (Hebb 1945c).

There were a number of problems that Hebb had to overcome in order to develop his neuropsychological theory and he mentions three of these in his notes: the inter-relatedness of psychological concepts; the assumption that behaviour is under sensory control; and the lack of neurophysiological data. He dealt with these problems by developing a set of postulates that became the building blocks of his theory. These were: that perception required learning, that synaptic change could account for learning, that neural activity could be separated from sensory input and that both perception and learning could be accounted for through the development of cell assemblies.

The idea that perception required learning was stimulated by the work of von Senden $(1932,1960)$ on the development of visual ability in congenitally blind people after surgical operations which enabled them to see for the first time. Hebb used the case studies in this book and the work of Riesen (1947), on monkeys reared in the dark, to argue that perception relied on learning. It was only after he developed the idea of perceptual learning that Hebb returned to his own $\mathrm{PhD}$ thesis and understood how he had mis-interpreted his own results. Hebb (1937) had concluded that visual ability of rats was innate as rats reared in total darkness could discriminate between two figures, but in his Precis (Hebb 1945c), he reported that the rats reared in darkness took much longer to make this discrimination than rats reared in the light as they had to undergo a period of perceptual learning once they were removed from the darkness (Hebb 1949a). Although Wertheimer (1951) disagreed with Hebb's interpretation of von Senden's results, they were crucial to Hebb's development of the concept of the cell assembly and the idea that perceptual organization occurs through a process of learning.

Hebb relied on two books for his background information on learning theory and the physiology of behaviour, Hilgard \& Marquis (1940) and Morgan (1943), both of which explained the synapse and neural connections as described by Lorente de No (1938). These books determined how Hebb thought synapses functioned. When Hebb was developing his ideas about the neural basis of behaviour in 1944 and 1945, there were no textbook descriptions of neurochemical transmission in the CNS and thus no neurotransmitters to discuss. Hebb, like everyone else, was working only with the idea of electrical transmission in the cortex. This meant that the brain was envisioned as a series of electrical circuits in which changes in "bio-electric fields" were thought to underlie learning (Hilgard \& Marquis 1940). The neurochemical synapse was not formally acknowledged until Eccles published his seminal paper (Eccles et al. 1954) and it was only 
after this that Eccles came to believe that synaptic transmission in the CNS could be chemical as well as electrical (Eccles 1976, 1982). Thus, Hebb's belief that synaptic change accounted for learning came from these books; he did not claim that the "Hebb synapse" idea was his own.

It was from Lorente de No's (1938) theory of recurrent (reverberating) nerve circuits that Hebb developed his idea of "cell assemblies". The concept of the cell assembly, with its reverberating circuits, meant that neural activity could continue in the absence of an external stimulus. Eccles had developed the idea of inhibitory synapses (Brooks \& Eccles 1947) but, although he wrote an essay on inhibition in the nervous system in 1934 (Hebb 1934), he did not incorporate the concept of inhibition into his theory; it had to wait for Milner's (1957) revision. The cell assembly theory provided a neural explanation for perceptual processes and learning as both relied on external input to develop a mental image (cell assembly). The concept of the phase sequence allowed cell assemblies to communicate and thus provided the neural basis for thought and other higher order mental processes.

Hebb completed the first five chapters of The Organization of Behavior in Florida and sent them to Edwin G. Boring at Harvard, Lashley and others for comment. He invited Lashley to be a co-author of the book, but Lashley was not impressed with the manuscript and declined co-authorship. Despite Lashley's negative opinion, Hebb submitted these chapters to Charles C. Thomas Publishers in 1947. These were sent to Henry Nissen to review and he sent Hebb comments on each chapter.

\section{Harvard and McGill: 1947- 49}

Edwin G. Boring, the Chairman of the Psychology Department at Harvard, invited Hebb to teach there during the 1947 summer session. One of the classes was a graduate seminar for which Hebb used mimeographed copies of his new manuscript. One of the students in this class was Mark Rosenzweig, who wrote:

"I took a graduate seminar with Donald $\mathrm{O}$. Hebb at Harvard in the summer of 1947 where the text was a mimeographed version of Hebb's influential book The Organization of Behavior which appeared in print in 1949. (I wish I had had the foresight to save that 1947 version.) Hebb's creative suggestions revitalized theorizing and research on learning and memory, and I benefitted directly from them and from further contacts with him" (Rosenzweig 1998).

Hebb had been offered a position as Professor of Psychology at McGill University and he arrived in Montreal in September 1947, starting his new career at McGill with as heavy a teaching load as he had left at Queen's University five years before. Now, however, much of his teaching was with graduate students and included courses in Comparative Psychology and Physiological Psychology, in addition to supervising the research projects of graduate and honours students. 
During his first year at McGill, Hebb wrote chapters 6 to 11 of The Organization of Behavior and sent them to Henry Nissen, Austen Riesen, Robert Blum and others for their comments. On 29 September 1948, Hebb mailed the completed version of his book to Charles $C$. Thomas Publishers under the title On Thought and Behavior. But Thomas returned Hebb's manuscript because he had a number of other books to publish and did not want to delay the publication of Hebb's book. It was turned down! With the support of letters from Frank Beach and Henry Nissen, however, John Wiley \& Sons agreed to publish the manuscript, and Hebb's book, now entitled The Organization of Behavior was finally published in the fall of 1949.

\section{What did Hebb say in The Organization of Behavior?}

In The Organization of Behavior, Hebb proposed a theory for the explanation of psychological concepts such as attention, perception and learning in terms of a set of neurophysiological postulates. To do this, he proposed three key ideas. First, he argued that the synaptic connections between neurons in the cortex increased in efficiency in response to the degree of temporal contiguity in their pre- and post-synaptic activity. This concept has been termed the "Hebb synapse" and forms the basis of the "Hebbian Learning Rule" which has been used to form the basic algorithm for learning. Second, Hebb proposed that collections of neurons that tended to fire together formed a cell assembly, whose activity persisted after a sensory stimulation and formed the neural representation of that stimulation. Third, he proposed that cognitive processes such as attention and thinking occurred when sets of cell assemblies were activated in sequence, in what he termed a "phase sequence" which was the basis for the "temporally organized processes of thinking" (Hebb 1949a). Synaptic plasticity and cell assemblies have since become central tenets in behavioural and cognitive neuroscience [Spatz 1996]. The concept of synaptic plasticity suggested that synapses were not fixed, but changed depending on their stimulation, and the concept of cell assemblies showed how a number of cells could be involved in the same psychological process through their specific synaptic connections.

Hebb was critical of the Pavlovian stimulus-response model of learning, on which Hull's learning theory was based (Hull 1943), and put emphasis on Tolman's stimulus-stimulus associations (Tolman 1932). Hebb was also critical of the Gestalt theory of perceptual processes (Kohler 1929). Using his neurophysiological theory, Hebb integrated the ideas of these prominent psychological theories through common neural processes. On the basis of his theory, Hebb also reinterpreted his own previous research on Penfield's neurosurgery patients, the development of intelligence, animal models of intelligence, and emotionality in chimpanzees. The first half of the book focused on providing a neural explanation for perception and learning, and presented Hebb's concepts of synaptic plasticity, the cell assembly and phase sequence. The second half of the book demonstrated how such a neurophysiological theory could explain the development of learning capac- 
ity, motivation, emotion, mental illness, and the growth and decline of intelligence. These ideas were so far ahead of their time that they were virtually untestable with the methods available and Hebb often made the point that future research was bound to prove them wrong as new information about the functioning of the nervous system became available.

\section{Reviews of Hebb's book: 1949-2004}

Fittingly, the published reviews of The Organization of Behavior were uniformly positive, even when they were critical. Kuhn (1950) stated that, "this book will probably come to be regarded as a landmark in psychological theory." Brogden (1950) wrote that, "The neural theory is admittedly gross, and probably impossible to test, but its presentation results in provocative discussion." Attneave (1950) stated "I believe The Organization of Behavior to be the most important contribution to psychological theory in recent years." In a lengthy review, Leeper (1950) stated "There are so many respects in which Hebb's book is so high in quality and is so delightfully written that it will have an assured status in psychology."

Of course, Hebb's book did live up to the reviewer's predictions and became one of the most important contributions to psychology in the 20th century. During the 1950's, Hebb's ideas were everywhere. Although Wertheimer (1951) criticized Hebb's views of the importance of learning in perception, Allport (1955) devoted an entire chapter (entitled "The association approach, cell assembly and phase sequence") to a discussion of Hebb's ideas on perception. In the second edition of his book on theories of learning, Hilgard (1956) added a separate section on Hebb's neuropsychological model and by 1959 , Koch's monumental seven volume survey of psychology as a science had a chapter by Hebb (Hebb 1959) and refered to Hebb in every volume (Koch 1959). The Organization of Behavior became one of the most highly cited books in psychology and neuroscience and was required reading for many university courses in a wide variety of disciplines.

After the publication of The Organization of Behavior, Physiological Psychology emerged as an active field of research. The book also stimulated new ideas in other areas of psychology, biology, computer science and early childhood education. It has been translated into 11 languages and in the year 2000 the Cognitive Science Millenium Project in selecting the 100 most influential books in cognitive science in the 20th century [http:// www.cogsci.umn.edu /OLD/calendar/ past_events /millennium/final.html], ranked The Organization of Behavior fourth (after Noam Chomsky, David Marr and Alan Turing).

The continued importance of The Organization of Behavior is indicated by the fact that at the 50th anniversary of its publication, it was reviewed almost as often as when it was originally published (Martinez \& Glickman 1994, Nicolelis et al. 1997, Sejnowski 1999). Since the 1966 paperback reissue of The Organization of Behavior was out of print, Peter Milner and I had it republished in 2002 and this reissue has also been reviewed (Tees 2003). Hebb's ideas of synaptic plasticity and cell assemblies have become 
fundamental concepts in psychology and neuroscience (Spatz 1996, Milner 2003, Kolb 2003, Sejnowski 2003, Hinton 2003) and the impact of Hebb's book on psychological theory has been compared with that of Darwin's Origin of Species on biological theory (Adams 1998). Posner \& Rothbart (2004) argue that Hebb's ideas provide the basis for an integration of the disparate sub-fields of psychology. We have examined the origins of The Organization of Behavior (Brown \& Milner 2003) and Cooper (2005) provides a history and commentary on the Hebb synapse and learning rule.

\section{Hebb's evaluation of his own book}

When Hebb was asked to discuss the development of his theory and its impact on psychology, he responded that he attempted to "deal with set and attention and perceptual generalization and learning in one theoretical framework, not have one approach for thinking, another for learning, and a third for perception -- the position in which the members of the Gestalt group found themselves" (Hebb 1959). Hebb continued to state that:

"My theory is the only one that attempts this, and in my opinion, to be quite frank, is consequently the only realistic attempt to deal theoretically with the problems of behavior. Skinner of course has avoided theory; Tolman and Guthrie have proposed approaches to the problem of constructing a theory, but both have remained, essentially, programmatic. Hull's is the only real alternative to mine; and the course of development of his ideas, from 1937 to 1951, has shown a narrowing of the range of phenomena dealt with, an increasingly clear set of difficulties to be encountered even in the narrow range with which his theory does deal, and an increasing concern with minor modifications of postulates as defensive measures to meet the attacks of critics. ..... Mine, in short, is the only attempt to deal with the thought process and perception in the framework of a theory of learning. It has serious defects, but no real competitor. This fact I see as the major "evidence for the system", together with the body of research that it has, directly or indirectly, stimulated" (Hebb 1959).

\section{Hebb as a teacher}

Hebb had a remarkable influence on the training of psychology students at McGill. Not only did he develop a graduate program that attracted very high quality students, he also taught a very popular introductory class and wrote a textbook of psychology (Hebb 1958). Hebb also taught a graduate seminar, which was attended by all psychology graduate students and is now legendary. Hebb was involved in the 1958 Colorado conference on the teaching of psychology (Garner et al 1959) and he carried his radical ideas about teaching (Hebb 1930) to the training of graduate students.

Hebb's ideas on the training of research students (Hebb 1966) were that: (1) You can't train people to do research in courses; it is learned by apprenticeship in a research setting. (2) Graduate student research capacity and promise cannot be evaluated by examinations, but by involving the student 
in research and then making an intuitive or clinical judgment of their promise. (3) Students should be given the opportunity to experience research as soon as possible, and as early as their third or fourth-year as honors students, so that they can be evaluated as thinkers and doers, not as memorizers. (4) A decision should be made on whether or not to accept a student into the $\mathrm{PhD}$ program after the first year, and a weak student should not be kept on, because this results in mediocre graduates. (5) You can train a student to write provided that you work closely with the student at all stages of the writing. Writing should be a main concern of the director of research. It is not subsidiary, not ancillary, not really distinguishable from the rest of the research experience. Hebb was very interested in training students to write (Hebb \& Bindra 1952) and would require them to rewrite drafts of their papers many times. Hebb defined psychology as a biological science and stated that it should be studied by objective methods, rather than by introspection, humanistic or subjective methods that are more suited to literature and the arts. Hebb's focus on the biological bases of behaviour and his methods for training students turned McGill into the foremost centre for physiological psychology (now behavioural neuroscience) in the world.

\section{Hebb's students and their research: 1947 - 1954}

The success of Hebb's educational methods are reflected in the success of his students, including Bernard Hymovitch, Donald Forgays, Mortimer Mishkin, Brenda Milner, Peter Milner, Ronald Melzack, Seth Sharpless, Woodburn Heron, Helen Mahut, Gordon Mogenson, Case Vanderwolf and legions of others who attended his introductory psychology class and graduate seminar and were motivated to pursue biological psychology as a career. Hebb used the theories that he had developed in The Organization of Behavior to direct the research of his students. Often his students and colleagues repeated and extended his old experiments in light of his new theory. Since Hebb was not a co-author on any of these papers, to understand how Hebb's research was influenced by his theory, one must read the publications of his students and colleagues. For example, Rabinovitch \& Rosvold (1951) developed a standardized procedure for the Hebb-Williams maze and tested rats with cortical damage and rats reared in a "free environment". Other students used the Hebb-Williams maze to test the effects of electroconvulsive shocks (Rishikof \& Rosvold 1953), environmental experience and lesions (Smith 1959), thalamic stimulation (Mahut 1962), the effects of blindness and early rearing experience (Hymovitch 1952), and the effects of environmental enrichment on learning and memory (Forgays \& Forgays 1952).

Beach \& Jaynes (1954) reviewed the literature on the effects of early experience on behaviour of animals and stated that: "A leader in this field is Hebb, whose The Organization of Behavior (1949) has been directly or indirectly responsible for a number of experiments reported in psychological journals during the last two or three years." Hebb's work stimulated research on the effects of early experience on problem solving, neuroanatomy and 
neurochemistry (Hunt 1979), and his ideas helped to facilitate the development of head start programmes using environmental enrichment for deprived children (Campbell et al. 1994).

Hebb did not work with patients after he left the MNI in 1939, but he did collaborate with Penfield through his students and colleagues, who often repeated studies on the effects of lesions on intelligence that Hebb began with Penfield. Rosvold \& Mishkin (1950) looked at the effects of prefrontal lobotomy on intelligence as Hebb (1939a) had done, Forgays (1952) looked at the development of cognitive dysfunction after surgery and Milner (1954) investigated the intellectual function of the temporal lobes as Hebb (1939b) had done. This research led to the groundbreaking work on patient HM, which revolutionized the study of the neural basis of memory (Scoville \& Milner 1957).

Hebb also continued the studies of fear and emotionality that he had started at the Yerkes Primate Laboratories, but instead of chimpanzees, he now used purebred Scottish terriers. The dogs were first tested in studies of the effects of early rearing experience on learning as Hebb had done with rats reared at home (Thompson \& Heron 1954), and then in studies of emotional behaviour (Clarke et al. 1951, Mahut 1958, Melzack 1952, 1954), and the development of social behaviour (Melzack \& Thompson 1956).

During the 1950's, work from Hebb's laboratory was often reported in the Montreal newspapers. For example, the work of Olds \& Milner (1954) on electrical stimulation of brain reward pathways was reported on the front page of the Montreal Gazette on 12 March 1954, under the headline "McGill opens vast new research field with brain 'pleasure area' discovery". The work on sensory deprivation (Bexton et al. 1954) was reported in the Montreal Gazette of 14 January 1954 under the headline "See, hear, feel nothing research shows bored brain acts queerly: Isolation tests at McGill pay human guinea pigs $\$ 20$ a day - but few can take it". The same research was treated more harshly in the New York Times of 15 April 1956, which linked Hebb's sensory deprivation experiments at McGill to brainwashing. The Montreal Gazette of 26 April 1956 ran a front page headline "Brainwashing defense found" and a second article entitled "McGill discovery will benefit military", which explained how the Defense Research Board of Canada had contracted the experiments on sensory deprivation to study "so-called brainwashing... used by opponents of western powers". This was at the time of the Korean War (1950-53), and the introduction of the term "brainwashing" in Edward Hunter's book Brainwashing in Red China (1951) led to the fear of brainwashing of captured soldiers. Although aspects of Hebb's sensory deprivation experiments were classified as secret, most of the results have been published, including a summary in Scientific American (Heron 1957). This work is still controversial today (McCoy 2006).

Hebb's studies of sensory deprivation also started an entire field of research and, in an introduction to a symposium which summarized the research on sensory deprivation stimulated by Hebb's ideas, Cobb (1961) states that: "When Hebb had the ingenious idea of studying perception in 
human beings by means of sensory deprivation and, especially, when he courageously acted on the idea and performed his experiments, he made a great step forward. It is only seven years since he published his first paper on this subject, but one has only to look at the content of this symposium to see how quickly and fruitfully the work was taken up by others."

\section{Hebb's writings following The Organization of Behavior}

With the completion of The Organization of Behavior, Hebb became one of the major theorists in the field of Physiological Psychology. He was chosen to review the field of Animal and Physiological Psychology for the first Annual Review of Psychology (Hebb 1950) and, in a paper on "The role of neurological ideas in psychology", Hebb (1951) compared his theory of behaviour to those of Tolman, Krech, Hull and the Gestaltists and presented evidence for the relevance of his neurological approach to the theory of personality. Hebb's presentation at the Association for the Study of Animal Behaviour (ASAB) meeting in London, England, focussed on the problem of separating genetic and environmental components of behaviour. In this paper, he stated that asking what percentage of behaviour is due to heredity and what percentage due to environment "... is exactly like asking how much of the area of a field is due to its length, how much due to its width" (Hebb 1953a). In this paper, he also criticized the ethologists for attempting to study innate behaviour before studying learning as he felt that all forms of behaviour involve some type of learning.

In his presidential address to the Canadian Psychological Association (CPA), Hebb (1953b) argued that human thought was the central problem for psychology. He further argued that the existence of thought was denied by stimulus-response behaviorists such as Thorndike, and not explained by the Gestalt theorists. Hebb then discussed how his cell assembly model could account for the concept of thought. Hebb \& Thompson (1954) discussed Hebb's research on chimpanzee emotional behaviour and his work on the importance of environmental experience in the development of behaviour and suggested that emotionality and psychopathology result from breakdowns in cell assemblies.

In his presidential address to Division 3 of the American Psychological Association (APA), Hebb (1955a) discussed the concept of motivation in terms of the CNS (Conceptual Nervous System). Hebb wrote this paper in response to B.F. Skinner who had stated that "the letters CNS be regarded as representing not the Central Nervous System, but the Conceptual Nervous System. Many theorists point out that they are not talking about the nervous system as an actual structure undergoing physiological or biochemical changes but only as a system with a certain dynamic output" (Skinner 1950). What Hebb showed was that conceptualizing psychological problems in physiological terms led to research on the neural basis of behaviour, as shown by the work of Moruzzi and Magoun on the brain stem arousal system and the results of Olds and Milner's studies of reward by 
electrical brain stimulation. He also presented the idea of an inverted $U$ shaped curve to describe the optimal arousal of behaviour.

In his presentation to the American Psychiatric Foundation, Hebb (1955b) again discussed the importance of environmental stimulation during development, relating it to levels of adjustment at maturity. In particular, Hebb pointed out that "a short period of deprivation of normal sensory input produces personality changes and a clear loss of capacity to solve problems" (Hebb 1955b). He used examples from his research on dogs and rats and the effects of sensory deprivation in humans to illustrate this point. Thus, in the years after the publication of The Organization of Behavior, Hebb was able to show how his theories could be applied to the study of the full range of psychological problems.

\section{Hebb's involvement in the promotion of psychology}

Hebb's promotion of research in Physiological Psychology at McGill, in combination with the research at the MNI made Montreal a world centre for brain research and attracted two major conferences in the early 1950's. The first was the Brain Mechanisms and Consciousness Symposium, which was held in Ste-Marguerite, Quebec, in August 1953 (Delafresnaye 1954). This meeting brought the top neuroscientists from all over the world to Quebec. These included H.W. Magoun, who presented a review of the ascending reticular activating system and wakefulness and $\mathrm{G}$. Moruzzi, who reported on the physiological properties of the brain stem reticular activating system. Walle Nauta, W.R. Hess, Mary Brazier, and E.D. Adrian (later Lord Adrian), all gave presentations, as did Wilder Penfield, W. Grey Walter and Herbert Jasper. Hebb spoke on the problem of consciousness and introspection in which he discussed his experiments on sensory deprivation. Lashley spoke on dynamic processes in perception and Lawrence Kubie spoke on psychiatric and psychoanalytic considerations of the problem of consciousness.

The second meeting, the 14th International Congress of Psychology, was held in Montreal in June 1954. It was presided over by Edward C. Tolman, the President of the APA and Edward A. Bott, the President of the CPA (Rosenzweig et al. 2000). Hebb was the Chairman of the Local Arrangements Committee, along with other faculty members from McGill and the University of Montreal (Proceedings 1954). Over 1000 psychologists from 31 countries, including Russia, attended this meeting, which had plenary talks by Jean Piaget, Wilder Penfield and Edward C. Tolman. The delegation of six Russians included E.N. Sokolov, A.N. Leontiev and E.A. Asratyan.

After Hebb's book was published, he was invited to give lectures at many scientific meetings and at universities throughout North America and Europe. Hebb's first major lecture was the James Arthur Lecture entitled "The evolution of thought and emotion", which he gave at the American Museum of Natural History in New York in 1948. In 1950 and 1951, he gave lectures in Chicago, Michigan and Yale. He also had a lecture tour of England in April and May of 1952; it was his first trip to Europe. During this trip, he 
gave three lectures at the University of London, one at Oxford and one at the Maudsley Hospital as well as an Association for the Study of Animal Behaviour Lecture on heredity and environment (Hebb 1953a). Hebb also gave the Hughlings Jackson Lecture at the Montreal Neurological Institute in 1958 and the Claude Bernard Lecture at the Universite de Montreal in 1966. Notes for many more lectures abound in his collected materials.

Hebb also became a spokesman for psychology as a science, both within Canada and internationally. He was elected the president of the CPA in 1953 and promoted the publication of high quality research in the Canadian Journal of Psychology, where many of his students published their papers. Hebb also worked tirelessly to increase support for research in psychology. He served on the Human Resources Research Advisory Committee of the Defense Research Board of Canada from 1951 to 1953, and lobbied the National Research Council to have a section for research in Experimental Psychology, which he chaired from 1956-62. He also served on the Board of Scientific Counselors of the National Institute for Mental Health from 1965 to 1969.

Hebb became a member of the APA in 1936 and attended most of the APA meetings between 1940 and 1973. He was also involved in administration of the APA as President of Division 3 (Experimental Psychology) in 1953 (Hebb 1955a) and President of the APA in 1959, the first non-American to be elected (Hebb 1960). In 1961, Hebb was awarded an APA Distinguished Contribution Award (Hebb 1963) and in 1973, he was invited to address the APA on "What Psychology is About" (Hebb 1973).

\section{Hebb's awards}

Throughout his career, Hebb received many honours, including the Warren Medal from the Society of Experimental Psychologists (1958), the distinguished scientific contribution award from the APA (1961), and an award from the Association for Research in Nervous Mental Disorders (1962). He was awarded the Claude Bernard Medal from the University of Montreal (1966), the Gold Medal from the APA (1974), the Society for Research in Child Development Distinguished Scientific Contribution Award (1979) and the CPADistinguished Scientific Contribution Award (1980). He was elected a Fellow of the Royal Society of Canada (1959) and the Royal Society of London (1966). He was given honorary doctorates by 15 Universities and was nominated for the Nobel Prize in Physiology and Medicine in 1965. These awards, from so many different societies, give some indication of the wide impact of his work.

\section{Hebb retires to Nova Scotia}

Hebb was the chairman of the Psychology Department at McGill from 1948 to 1958 and the Vice-Dean of Biological Sciences from 1964 to 1966. He was then elected Chancellor of McGill University from 1970 to 1974. As Chancellor, he presided over many university events and gave a number of public lectures, such as his lecture on the importance of a university education (Hebb 1971). 
In 1977, Hebb retired to Marriot's Cove, Nova Scotia, only a few miles from Chester, his birthplace. He became a Professor Emeritus at Dalhousie University and commuted to Halifax once a week for lunch with colleagues, including Graham Goddard, Lynn Nadel, Ray Klein, John Fentress and their students, who included Carol Barnes, Bruce McNaughton and Rob Douglas. Hebb always enjoyed sailing and went out in his boat, "The Raven" whenever he could. While he was "retired", he wrote his third book, Essay on Mind (Hebb 1980a), a summary of his ideas on the biological basis of mind. He also gave a number of interviews to Psychology Today, wrote an introspective account of aging (Hebb 1978) and completed his autobiography (Hebb 1980b, c).

\section{The legacy of Hebb's work}

Hebb died on 20 August 1985, following complications from surgery. Numerous obituaries were published which described his legacy to every area of psychology and neuroscience (Harnad 1985, Fentress 1987, Klein 1989). Modern neuropsychology is indebted to Hebb's work with Penfield. The study of environmental effects on development derives from Hebb's pet rats reared at home. Computer models of the brain are based on Hebb's ideas of the synapse and cell assembly. Long-term potentiation (Bliss \& Lomo 1973 ) is the experimental analysis of Hebbian synaptic plasticity. The work of Hubel and Wiesel on neural plasticity of sensory system development (Weisel \& Hubel 1965) derives from the first five chapters of The Organization of Behavior (Stent 1973). The field of computational neuroscience is based largely on Hebb's ideas (Sommer \& Wennekers 2003). His emphasis on the effects that the timing of neural impulses have on brain function is in keeping with the discovery of spike-time-dependent synaptic plasticity (Bi \& Poo 2001, Sejnowski 1999). In addition, studies of the neural bases of emotion, motivation, reward, and pain pathways derive from Hebb's ideas and the research of his students. Although a 2002 study ranked Hebb as only the 19th most eminent psychologist of the 20th Century (Haggbloom et al. 2002), a greater awareness of what we owe to Hebb should increase this ranking substantially.

Acknowledgements. I would like to thank the McGill University archives, the Dalhousie University library and archives, the University of Chicago, Harvard University, the University of California, Berkeley, the University of British Columbia archives and Queen's University, Kingston, Ontario, for access to Hebb's files. Thanks to Mary Ellen Hebb and Jane Hebb Paul for access to family photographs and letters and to Gordon Hebb for access to unpublished Hebb family genealogical research. Thanks also to Peter Milner, Steve Glickman, and other students of Hebb for sharing their information. Thanks to Melissa MacKinnon at the The Little White Schoolhouse Museum, Truro, NS for finding Hebb's student records. 


\section{REFERENCES}

Adams P (1998) Hebb and Darwin. J Theor Biol 195:419-438

Allport FH (1955) Theories of perception and the concept of structure. John Wiley and Sons, New York

Attneave F (1950) The organization of behavior: a neuropsychological theory. Amer J Psych 63:633-635

Babkin BP (1942) How I came to Dalhousie. J Mt Sinai Hospital 9:168-175

Beach FA, Jaynes J (1954) Effects of early experience upon the behavior of animals. Psych Bull 51:239-263

Bell R (1977) Wilder Penfield: his legacy to neurology. Can Med Assn J 18:1365 $-1377$

Bexton WH, Heron W, Scott RH (1954) Effects of decreased variation in the sensory environment. Can J Psychol 8:70-76

Bi G, Poo M (2001) Synaptic modification by correlated activity: Hebb's postulate revisited. Annu Rev Neurosci 24:139-166

Bliss TV, Lomo T (1973) Long-lasting potentiation of synaptic transmission in the dentate area of the anaesthetized rabbit following stimulation of the perforant path. J Physiol 232:331-356

Brogden WJ (1950) Organization of behavior. Scientific Monthly, 17:283-284

Brooks CM, Eccles JC (1947) An electrical hypothesis of central inhibition. Nature 159:760-764

Brown RE, Milner PM (2003) The legacy of Donald O. Hebb: more than the Hebb synapse. Nature Rev Neurosci 4:1013-1019

Campbell FA, Ramey CT (1994) Effects of early intervention on intellectual and academic achievement: a follow-up study of children from low-income families. Child Dev 65:684-98

Clarke RS, Heron W, Fetherstonhaugh ML, Forgays DG, Hebb DO (1951) Individual differences in dogs: preliminary report on the effects of early experience. Can J Psych 5:150-156

Cobb S (1961) Foreword. In: Solomon P, Kubzansky PE, Leidermann PH, Mendelson JH, Trumbell R, Wexler D (eds) Sensory deprivation. Harvard University Press, Cambridge, Mass

Cooper SJ (2005) Donald O. Hebb's synapse and learning rule: a history and commentary. Neurosci Biobehav Rev 28:851-874

Delafresnaye JF (ed) (1954) Brain mechanisms and consciousness. Charles C. Thomas Publishers, Springfield, Illinois

Dewsbury DA (2002) The Chicago five: a family group of integrative psychobiologists. History Psychol 5:16-37

Eccles $\mathbf{J}$ (1976) From electrical to chemical transmission in the central nervous system. Notes \& Records Royal Soc Lond 30:219-230

Eccles JC (1982) The synapse: from electrical to chemical transmission. Ann Rev Neurosci 5:325-339

Eccles JC, Fatt P, Koketsu K (1954) Cholinergic and inhibitory synapses in a pathway from motor-axon collaterals to motoneurones. J Physiol (Lond) 126:524562

Feindel W (1992) Brain physiology at the Montreal Neurological Institute: some historical thoughts. J Clin Neurophysiol 9:176-194

Fentress JC (1987) D.O. Hebb and the developmental organization of behavior. Dev Psychobiol 20:103-109 
Ferguson GA (1993) Psychology in Canada: 1939-45. Can Psych 33:697-705

Forgays DG (1952) Reversible disturbances of function in man following cortical insult. J Comp Physiol Psych 45:209-215

Forgays DG, Forgays JW (1952) The nature of the effect of free-environmental experience in the rat. J Comp Physiol Psych 45:322-328

Garner WR, Hunt HF, Taylor DW (1959) Education for research in psychology. Amer Psych 14:167-179

Haggbloom SJ, Warnick R, Warnick JE (2002) The 100 most eminent psychologists of the 20th century. Rev Gen Psych 6:139-152

Harnad S (1985) D.O. Hebb: father of cognitive psychobiology: 1904-1985. Behav Brain Sci 8: page765

Hebb DO (1925) 25 class history. Dalhousie Gazette, 25-29

Hebb DO (1930) Elementary school methods. Teacher's Magazine 12:23-26

Hebb DO (1932) Conditioned and unconditioned reflexes and inhibition. MA thesis, McGill University, Montreal, Quebec

Hebb DO (1934) The interpretation of experimental data on neural action. Unpublished manuscript

Hebb DO (1936) The innate organization of visual perception in the rat. PhD thesis, Harvard University, Boston, Mass

Hebb DO (1937) The innate organization of visual activity: I. Perception of figures by rats reared in total darkness. J Genetic Psych 51:101-126

Hebb DO (1938) Studies of the organization of behavior. I. Behavior of the rat in a field orientation. J Comp Psychol 25:333-353

Hebb DO (1939a) Intelligence in man after large removals of cerebral tissue: report of four left frontal lobe cases. J Gen Psychol 21:73-87

Hebb DO (1939b) Intelligence in man after large removals of cerebral tissue: defects following right temporal lobotomy. J Gen Psychol 21: 437-446

Hebb DO (1941) Higher level difficulty in verbal test material. Bull Can Psych Assn $1: 29$

Hebb DO (1942) The effects of early and late brain injury upon test scores, and the nature of normal adult intelligence. Proc Amer Phil Soc 85:275-292

Hebb DO (1945a) Man's frontal lobes: a critical review. Arch Neurol Psychiatry $54: 10-24$

Hebb DO (1945b) The forms and conditions of chimpanzee anger. Bull Can Psych Assn 5:32-35

Hebb DO (1945c) Precis: The structure of a set of neuropsychological speculations. Unpublished manuscript

Hebb DO (1946) On the nature of fear. Psych Rev 53:259-276

Hebb DO (1947a) Spontaneous neurosis in chimpanzees: theoretical relations with clinical and experimental phenomena. Psychosom Med 9:3-19

Hebb DO (1947b) The effects of early experience on problem solving at maturity. Amer Psych 2:306-307

Hebb DO (1949a) The organization of behavior: a neuropsychological theory. Wiley, New York [Reprinted 2002 by Lawrence Erlbaum Associates, Mahwah, New Jersey]

Hebb DO (1949b) Temperament in chimpanzees: I. Method of analysis. J Comp Physiol Psych 42:192-206

Hebb DO (1950) Animal and physiological psychology. Ann Rev Psych 1:173-188

Hebb DO (1951) The role of neurological ideas in psychology. J Personality 20:3955 
Hebb DO (1953a) Heredity and environment in mammalian behaviour. Br J Anim Behav 1:43-47

Hebb DO (1953b) On human thought. Can J Psych 7:99-110

Hebb DO (1954) The problem of consciousness and introspection. In: Delafresnaye JF (ed) Brain mechanisms of consciousness. Charles C. Thomas Publishers, Springfield, Illinois, p 402-421

Hebb DO (1955a) Drives and the C.N.S. (conceptual nervous system). Psych Rev 62:243-254

Hebb DO (1955b) The mammal and his environment. Amer J Psychiat 111:826831

Hebb DO (1958) A textbook of psychology. Saunders, Philadelphia

Hebb DO (1959) A neuropsychological theory. In: Koch S (ed) Psychology: a study of a science, Vol 1. McGraw-Hill, New York, p 622-643

Hebb DO (1960) The American revolution. Amer Psychol 15:735-745

Hebb DO (1963) The semiautonomous process: its nature and nurture. Amer Psychol 18:16-27

Hebb DO (1966) Education for research. Can Feder News 8:53-57

Hebb DO (1971) The nature of a university education. McGill J Educ 6:5-14

Hebb DO (1974) What psychology is about. Amer Psychol 29:71-79

Hebb DO (1978) On watching myself get old. Psych Today 12(6):15-23

Hebb DO (1980a) Essay on mind. L Erlbaum Associates, Hillsdale, NJ

Hebb DO (1980b) D.O. Hebb. In: Lindzey G (ed.). A history of psychology in autobiography, Vol VII. WH Freeman, San Francisco, p 273-309

Hebb DO (1980c) An account of my life written for my daughters and grandchildren. Unpublished manuscript

Hebb DO (1980d) This is how it was: fifty years in psychology, forty years a psychologist. Presentation at the Canadian Psychology Association Meeting, Halifax, Nova Scotia. Unpublished

Hebb DO, Bindra D (1952) Scientific writing and the general problem of communication. Amer Psychol 7:569-573

Hebb DO, Foord EN (1945) Errors of visual recognition and the nature of the trace. J Exp Psych 35:335-348

Hebb DO, Morton NW (1943) The McGill adult comprehension examination: verbal situation and picture anomaly series. J Educ Psych 34:16-25

Hebb DO, Morton NW (1944) Note on the measurement of adult intelligence. J Gen Psychol 30:217-223

Hebb DO, Penfield W (1940) Human behavior after extensive bilateral removal from the frontal lobes. Arch Neurol Psychiatry 42:421- 438

Hebb DO, Thompson WR (1954) The social significance of animal studies. In: Lindzey $\mathrm{G}$ (ed) Handbook of social psychology, Vol 1. Addison-Wesley, Cambridge Mass, p 532-561

Hebb DO, Williams KA (1946) A method of rating animal intelligence. J Gen Psychol 34:59-65

Heron W (1957) The pathology of boredom. Sci Amer 196:52-56

Hilgard ER (1956) Theories of learning, 2nd edn. Appleton-Century-Crofts New York

Hilgard ER, Marquis DG (1940) Conditioning and learning. Appleton-CenturyCrofts, New York

Hinton G (2003) The ups and downs of Hebb synapses. Can Psychol 44:10-13

Hull CL (1943) Principles of behavior: an introduction to behavior theory. AppletonCentury, New York 
Hunt J M (1979) Psychological development: early experience. Ann Rev Psych 30:103-143

Hunter E (1951) Brainwashing in red China: the calculated destruction of men's minds. Vanguard Press, New York

Hymovitch B (1952) The effects of experimental variations on problem solving in the rat. J Comp Physiol Psychol 45:313-321

Kingsbury FA (1946) A history of the department of psychology at the University of Chicago. Psych Bull 43:259-271

Klein RM (1989) The Hebb legacy. Can J Exp Psych 53:1-3

Koch S 1959) Psychology: a study of a science, 7 volumes. McGraw-Hill, New York

Kohler W (1929) Gestalt psychology. H Liveright, New York

Kolb B (2003) The impact of the Hebbian learning rule on research in behavioural neuroscience. Can Psychol 44:14-16

Krech D, Rosenzweig MR, Bennett EL (1962) Relations between chemistry and problem-solving among rats raised in enriched and impoverished environments. J Comp Physiol Psychol 55:801-807

Kuhn MH (1950) Hebb, D. O. Organization of behavior: a neuropsychological theory. Ann Amer Acad Pol Soc Sci 217:216-217

Lashley KS (1929) Brain mechanisms and intelligence: a quantitative study of injuries to the brain. University of Chicago Press, Chicago [Reprinted 1963, Dover Press, New York]

Lashley KS (1930) Basic neural mechanisms in behavior. Psych Rev 37:1-24

Leeper R (1950) The organization of behavior: a neuropsychological theory (review). J Abnorm Soc Psychol 45:768-775

Lorente de No R (1938) Synaptic stimulation of motoneurons as a local process. J Neurophysiol 1:195-206

MacLeod EJ (1990) Petticoat doctors: the first forty years of women in medicine at Dalhousie University. Pottersfield Press, Lawrencetown, NS

Mahut H (1958) Breed differences in the dog's emotional behaviour. Can J Psych 12:35-44

Mahut H (1962) Effects of subcortical electrical stimulation on learning in the rat. $J$ Comp Physiol Psych 55:472-477

Martinez JL Jr, Glickman SE (1994) Hebb revisited: perception, plasticity, and the Hebb synapse. Contemp Psychol 39:1018-1020

McBride AF, Hebb DO (1948) Behavior of the captive bottle-nose dolphin, Tursiops truncatus. J Comp Physiol Psych 41:111-123

McCoy AW (2006) A question of torture: CIA interrogation, from the cold war to the war on terror. Metropolitan Books, New York

Melzack R (1952) Irrational fears in the dog. Can J Psych 6:141-147

Melzack R (1954) The genesis of emotional behavior: an experimental study of the dog. J Comp Physiol Psych 47:166-168

Melzack R, Thompson WR (1956) Effects of early experience on social behaviour. Can J Psych 10:82-90

Milner B (1954) Intellectual function of the temporal lobes. Psych Bull 51:42-62

Milner PM (1957) The cell assembly: Mark II. Psych Rev 64:242-252

Milner PM (2003) A brief history of the Hebbian learning rule. Can Psychol 44:5-9

Morgan CT (1943) Physiological psychology. McGraw-Hill Book Company Inc, New York

Nicolelis MA, Fanselow EE, Ghazanfar AA (1997) Hebb's dream: the resurgence of cell assemblies. Neuron 19:219-221 
Olding HH Jr (1976) Olding and allied families and descendents of Nicolas Purdue Olding of Merigomish, Nova Scotia. Privately published by Herbert Harris Olding, Jr, East Hartford, CT 06108

Olds J, Milner P (1954) Positive reinforcement produced by electrical stimulation of septal area and other regions of rat brain. J Comp Physiol Psychol 47:419-427

Patterson FH (1955) John Patterson the founder of Pictou Town. Truro Publishing and Printing Co, Truro, Nova Scotia. See also: Patterson G (1877/1972)A history of the county of Pictou, Nova Scotia. Dawson Brothers, Montreal, Quebec

Posner MI, Rothbart MK (2004) Hebb's neural networks support the intergration of psychological science. Can Psychol 45:265-278

Proceedings of the Fourteenth International Congress of Psychology, Montreal, June 1954. North Holland Publishing Company, Amsterdam

Queen's University (1940-41) Course calendar. Departmental prescriptions Mental and Moral Philosophy, p 142-148

Rabinovitch MS, Rosvold HE (1951) A closed-field intelligence test for rats. Can J Psych 5:122-128

Riesen AH (1947) The development of visual perception in man and chimpanzee. Science 106:107-108

Rishikof JR, Rosvold HE (1953) Effects of electroconvulsive shocks on the performance of the rat in the closed-field test. Can J Psych 7:29-33

Rosenzweig MR (1998) Some historical background of topics in this conference. Neurobiol Learn Memory 70:3-13

Rosenzweig MR, Holtzman WH, Sabourin M, Belanger D (2000) History of the International Union of Psychological Science. Psychology Press, Hove, UK

Rosvold HE, Mishkin M (1950) Evaluation of the effects of prefrontal lobotomy on intelligence. Can J Psych 3:122-127

Scoville WB, Milner B (1957) Loss of recent memory after bilateral hippocampal lesions. J Neurol Neurosurg Psychiatry 220:11-21

Sejnowski TJ (1999) The book of Hebb. Neuron 24:773-776

Sejnowski TJ (2003) The once and future Hebb synapse. Can Psychol 44:17-20

Shore DI, Stanford L, Maclnnes JW, Klein RM, Brown RE (2001) Of mice and men: virtual Hebb-Williams mazes permit comparison of spatial learning across species. Cognitive, Affective \& Behav Neurosci 1:83-89

Silver A (1993) Catherine Olding Hebb (1911-1978). In: Bindman L, Brading A, Tansey $\mathrm{T}$ (eds) Women physiologists: an anniversary celebration of their contributions to British physiology. Portland Press, London, p 123-127

Skinner BF (1950) Are theories of learning necessary? Psych Rev 57:193-216

Smith CJ (1959) Mass action and early environment in the rat. J Comp Physiol Psych 52:154-156

Sommer FT, Wennekers T (2003) Models of distributed associative memory networks in the brain. Theory in Biosciences 122:55-69

Spatz HC (1996) Hebb's concept of synaptic plasticity and neuronal cell assemblies. Behav Brain Res 78:3-7

Stent GS (1973) A physiological mechanism for Hebb's postulate of learning. Proc Nat Acad Sci USA 70:997-1001

Teal SW (1994) The Hebb mill affair: the history of the Hebb family (1682-1994). Privately published by Scott Winston Teal, Lower Sackville, Nova Scotia

Tees RC (2003) The organization of behavior: a neuropsychological theory. Can Psychol 4:74-76 
Thompson WR, Heron W (1954) The effects of restricting early experience on the problem-solving capacity of dogs. Can J Psych 8:17-31

Tolman EC (1932) Purposive behavior in animals and men. The Century Co, New York

van Praag H, Kempermann G, Gage FH (2000) Neural consequences of environmental enrichment. Nat Rev Neurosci 1:191-198.

von Senden M (1932) Raum- und Gestaltauffassung bei Operierten Blindgebornen von und nach der Operation. JA Barth, Liepzig

von Senden M (1960) Space and sight: the perception of space and shape in the congenitally blind before and after operation. Methuen \& Co, London (English translation by Peter Heath, with appendices by AH Riesen, GJ Warnock and JZ Young, and a select bibliography of books and papers citing this work)

Wiesel TN, Hubel DH (1965) Comparison of the effects of unilateral and bilateral eye closure on cortical unit responses in the kitten. J Neurophysiol 28:1029-1040

Wertheimer M (1951) Hebb and Senden on the role of learning in perception. Amer J Psych 64:133-137. 
